\title{
No difference in platelet activation or inflammation markers after diets rich or poor in vegetables, berries and apple in healthy subjects
}

\section{Freese, Riitta}

2004-01-06

Freese , R , Vaarala , O , Turpeinen , A M \& Mutanen , M 2004 , ' No difference in platelet activation or inflammation markers after diets rich or poor in vegetables, berries and apple in pÿhealthy subjects ' , European Journal of Nutrition , vol. 43 , no. 3 , pp. 175182 . https://doi.org/10.1007/s00394-00

http://hdl.handle.net/10138/298184

https://doi.org/10.1007/s00394-004-0456-4

publishedVersion

Downloaded from Helda, University of Helsinki institutional repository.

This is an electronic reprint of the original article.

This reprint may differ from the original in pagination and typographic detail.

Please cite the original version. 
Riitta Freese

Outi Vaarala

Anu M. Turpeinen

Marja Mutanen

\section{No difference in platelet activation or inflammation markers after diets rich or poor in vegetables, berries and apple in healthy subjects}

effects of compounds found in vegetables and fruits, such as flavonoids. Aim of the study To study the effects of high and low intake of vegetables, berries and apple on platelet function and inflammatory markers. Methods The study was a randomised, controlled parallel human dietary intervention with healthy female and male volunteers $(n=77,19-52 y)$. Nineteen healthy volunteers served as controls. The volunteers consumed one of four strictly controlled isocaloric 6-week diets containing either 810 or $196 \mathrm{~g} / 10 \mathrm{MJ}$ of vegetables, berries and apple and rich either in linoleic acid (11\% of energy, en $\%)$ or oleic acid (12 en\%). Blood and three 24-hour urine samples were collected at the beginning and at the end of the study period for analyses of various markers of platelet function and inflammation. Results No differences between the treatment groups were seen in platelet count or volume, markers of platelet activation (ex vivo aggregation to $\mathrm{ADP}$ and thrombin receptor activating peptide, protein kinase $\mathrm{C}$ activity, urinary 2,3-dinor-thromboxane $\mathrm{B}_{2}$ excretion, plasma P-selectin), plasma intercellular adhesion molecule-1, sensitive C-reactive protein, or antiphospholipid antibodies. Conclusions The results indicate that in healthy volunteers 6-week diets differing markedly in the amounts of vegetables, berries and apple do not differ in their effects on platelets or inflammation.

Key words vegetables - fruit blood platelets - inflammation dietary intervention

\section{Introduction}

Based on epidemiological data, diets rich in vegetables and fruit are considered to prevent coronary heart disease [1]. These effects have often been explained by the antioxidant effects of plant compounds. However, it is plausible that also other mechanisms, e.g. antithrombotic or anti-inflammatory effects, are involved.

Platelets play a crucial role in thrombosis but are also involved in atherogenesis. The effects of dietary fatty acids on platelet function have been studied actively [2] but much less information is available on the effects of other dietary constituents. Vegetables and fruit contain several molecules which could affect platelets. Platelet activation is modulated by oxygen free radicals [3], and there is evidence that antioxidant vitamins could decrease platelet function in humans [4-6]. The possible antithrombotic effects of flavonoids have been of large interest lately because they inhibit platelet function by several mechanisms in vitro [7-9]. Endothelial function and inflammation are firmly associated with atherosclerosis and thrombosis [10-12] and may be affected by dietary components [13-15]. Other factors associated with the risk of thrombosis are antiphospholipid antibodies [16-18] which have been reported to be associated with platelet and blood coagulation activation and lipid peroxidation [19]. 
Vegetables and fruit are a rich source of several nutrients and other possible active compounds and their beneficial effects are hardly explained by single components. Furthermore, part of the health promoting effects of vegetables and fruit may be due to their low content of energy and saturated fat. Some studies even suggest that their intake may be merely a marker of an otherwise healthful behaviour [20]. Controlled intervention studies on the effects of vegetables and fruit are thus clearly needed. We have carried out a strictly controlled dietary intervention with healthy volunteers to study how diets which differ markedly in the amounts of vegetables and fruit affect several markers associated with atherosclerosis or thrombosis [21]. In the present paper we report the results related to platelets and inflammation.

\section{Subjects and methods}

The dietary intervention was carried out in a strictly controlled way at the Division of Nutrition, University of Helsinki. The study design has been published previously [21]. The Ethics Committee of the Faculty of Agriculture and Forestry of the University of Helsinki approved the study protocol. All subjects gave their informed consent before the study.

\section{Subjects}

Healthy human volunteers were recruited among students and employees from the Viikki campus of the University of Helsinki. Eighty healthy volunteers started the study but three female subjects dropped out because of personal reasons. Four of the volunteers were regular smokers and oral contraceptives were used by $51 \%$ of the female subjects evenly distributed between the groups. Nineteen healthy subjects who kept their habitual diet constant (checked by dietary records) served as controls. The baseline characteristics of the subjects are shown in Table 1. Habitual diet of the subjects was checked before the intervention by 3 - $d$ food records and was found adequate. Furthermore, the treatment groups did not differ in this respect [21].

\section{Study design and diets}

The study was a parallel intervention. The volunteers were assigned to four treatment groups to have one of the four experimental diets for 6 weeks. The subjects had lunch every weekday at the Division of Nutrition. After lunch they took food for the rest of the day and for the next morning and on Fridays for the whole weekend with them. The experimental foods provided $90 \%$ of the daily energy (en\%) and the subjects had to choose the other $10 \mathrm{en} \%$ from a limited list of foods free of fat and cholesterol and low in antioxidants (sweets, sugar, grain products, limited amount of alcoholic beverages excluding red wine and berry wines, soft drinks, and selected vegetables/fruit). The study foods were weighed for each subject according to the energy needs (menus 7-16 $\mathrm{MJ} / \mathrm{d}$ ) and the amount of food was adjusted if there were changes in body weight (monitored twice a week).

The experimental diets consisted of normal foods and were either poor (diets P1 and M1) or rich (diets P2 and M2) in vegetables, berries and apple, and either rich in linoleic acid ( $11 \mathrm{en} \%$; diets P1 and P2) or oleic acid (12 en\%; diets M1 and M2) (Table 2). Energy intakes in the low-vegetable diets were adjusted by sugar and starch. The intakes of total (33 en $\%$ ) and saturated fat (10 en $\%$ ), $\mathrm{n}-3$ fatty acids ( $0.4 \mathrm{en} \%)$, protein (13 en $\%)$, and total carbohydrates (54 en\%, including fiber) were similar in all diets. Major differences between the nutrient intakes

Table 1 Baseline characteristics of the subjects and mean dietary energy intake levels during the experimental diets. Values are mean (range or SD)

\begin{tabular}{|c|c|c|c|c|c|c|}
\hline \multirow[b]{2}{*}{ Variable } & \multicolumn{4}{|l|}{ Treatment group } & \multirow{2}{*}{$\begin{array}{l}\text { Difference } \\
\text { between groups }^{b}\end{array}$} & \multirow[b]{2}{*}{$\begin{array}{l}\text { Control group } \\
n=19\end{array}$} \\
\hline & $\begin{array}{l}\mathrm{P} 1^{\mathrm{a}} \\
\mathrm{n}=18\end{array}$ & $\begin{array}{l}\mathrm{P} 2 \\
\mathrm{n}=20\end{array}$ & $\begin{array}{l}M 1 \\
n=20\end{array}$ & $\begin{array}{l}\text { M2 } \\
n=19\end{array}$ & & \\
\hline Females/males ( $n$ ) & $13 / 5$ & $15 / 5$ & $15 / 5$ & $14 / 5$ & & $15 / 4$ \\
\hline Age (y) & $25.4(19-38)$ & $26.2(19-50)$ & $25.5(20-52)$ & $23.3(19-37)$ & 0.584 & $32.7(22-50)$ \\
\hline BMI $\left(\mathrm{kg} / \mathrm{m}^{2}\right)$ & $22.1(18.5-33.6)$ & $23.1(18.6-33.7)$ & $22.9(19.1-29.9)$ & $22.1(17.9-25.9)$ & 0.738 & $23.2(19.0-28.9)$ \\
\hline Total cholesterol (mmol/L) & $4.30(0.49)^{c}$ & $4.76(0.81)^{c, d}$ & $4.92(0.83)^{d}$ & $4.37(0.66)^{c, d}$ & 0.012 & $4.91(0.71)$ \\
\hline Total triacylglycerols ( $\mathrm{mmol} / \mathrm{L}$ ) & $0.86(0.26)$ & $0.98(0.39)$ & $1.01(0.34)$ & $0.95(0.39)$ & 0.610 & $1.01(0.47)$ \\
\hline Energy level $(\mathrm{MJ} / \mathrm{d})^{\mathrm{e}}$ & $9.8(1.4)$ & $10.0(2.0)$ & $10.7(2.3)$ & $10.0(1.7)$ & 0.528 & - \\
\hline
\end{tabular}

a The treatment groups are named according to the experimental diets: $P 1$ rich in linoleic acid and low in vegetables; $P 2$ rich in linoleic acid and high in vegetables, berries and apple; $M 1$ rich in oleic acid and low in vegetables; and $M 2$ rich in oleic acid and high in vegetables, berries and apple

${ }^{b}$ The $p$-value of the difference between the treatment groups (one-way ANOVA or Kruskall-Wallis one-way analysis of variance)

$c, d$ Groups with different superscript letters differ significantly $(p<0.05$, post-hoc analysis of Tukey)

e Mean energy intake level during the experimental period (fiber is included in the total energy) 
Table 2 The calculated fatty acid compositions and intakes of some antioxidants and certain foods in the experimental diets

\begin{tabular}{|c|c|c|c|c|}
\hline \multirow[b]{2}{*}{ Nutrient/food } & \multicolumn{4}{|c|}{ Experimental diet } \\
\hline & $P 1^{a}$ & P2 & M1 & M2 \\
\hline Total SFA $(\text { en } \%)^{c}$ & 10.4 & 10.0 & 10.4 & 10.0 \\
\hline Total MUFA (en\%) & 8.0 & 7.8 & 15.8 & 15.7 \\
\hline Oleic acid (18:1 n-9) (en\%) & 4.5 & 4.5 & 12.3 & 12.3 \\
\hline Total PUFA (en\%) & 10.9 & 11.1 & 3.1 & 3.2 \\
\hline Linoleic acid (18:2 n-6) (en\%) & 10.0 & 10.1 & 2.1 & 2.2 \\
\hline $\mathrm{P} / \mathrm{S}$ ratio & 1.0 & 1.1 & 0.3 & 0.3 \\
\hline Vitamin C (mg/10 MJ) & 105 & 333 & 105 & 333 \\
\hline Total carotenoids (mg/10 MJ) & 5.2 & 16.9 & 5.2 & 16.9 \\
\hline$\beta$-carotene (mg/10 MJ) & 3.0 & 10.1 & 3.0 & 10.1 \\
\hline Vitamin E (mg TE/10 MJ) & 28 & 32 & 8 & 12 \\
\hline Vitamin E/PUFA (mg TE/g) & 1.0 & 1.1 & 1.0 & 1.4 \\
\hline Quercetin (mg/10 MJ) & 2.6 & 24.1 & 2.6 & 24.1 \\
\hline Folate ( $\mu \mathrm{g} / 10 \mathrm{MJ})$ & 295 & 421 & 295 & 421 \\
\hline Fresh or frozen vegetables ${ }^{d}(\mathrm{~g} / 10 \mathrm{MJ})$ & 167 & 440 & 167 & 440 \\
\hline Fresh fruits ${ }^{\mathrm{e}}(\mathrm{g} / 10 \mathrm{MJ})$ & 54 & 166 & 54 & 166 \\
\hline Frozen berries ( $(\mathrm{g} / 10 \mathrm{MJ})$ & 0 & 204 & 0 & 204 \\
\hline
\end{tabular}

a The experimental groups were on following diets: $P 1$ rich in linoleic acid and low in vegetables; $P 2$ rich in linoleic acid and high in vegetables, berries and apple; $M 1$ rich in oleic acid and low in vegetables; and $M 2$ rich in oleic acid and high in vegetables, berries and apple

b SFA saturated fatty acids; MUFA monounsaturated fatty acids; PUFA polyunsaturated fatty acids

c en\% \% of total energy

d Most abudant vegetables in the diets P2 and M2 were: carrot, tomato, cabbage, cucumber, broccoli, onion, and french beans. In diets P1 and M1: carrot, cabbage, cucumber, chinese cabbage and tomato

e Fruits in the diets $\mathrm{P} 2$ and $\mathrm{M} 2$ were mainly unpeeled apple; in diets $\mathrm{P} 1$ and $\mathrm{M} 1$ banana and peeled apple

${ }_{f}$ Most abudant berries in diets $\mathrm{P} 2$ and $\mathrm{M} 2$ were: strawberry, raspberry, bilberry, black currant and lingonberry

were in antioxidants and unsaturated fatty acids (Table 2). According to earlier studies, the effects of high intakes of linoleic and oleic acids on platelets do not differ [22-24] but the fatty acid modifications were interesting in respect of other markers [21].

The subjects kept their normal lifestyle during the experimental period. The control subjects kept their habitual diet (checked by repeated dietary records) but gave the same blood and urine samples as the study subjects.

\section{Compliance with the diets}

Compliance with the experimental diets was good according to study diaries and biochemical markers [21, 25]. Plasma vitamin $C$ and $\beta$-carotene increased in the high-vegetable groups $(\mathrm{P} 2:+2.6$ and $+0.6 \mu \mathrm{mol} / \mathrm{L}$; $\mathrm{M} 2:+3.0$ and $+0.5 \mu \mathrm{mol} / \mathrm{L}$, respectively) while the respective concentrations in the low-vegetable groups did not change (P1: -0.1 and $+0.1 \mu \mathrm{mol} / \mathrm{L} ; \mathrm{M} 1:+0.2$ and $0.1 \mu \mathrm{mol} / \mathrm{L})$. Also other carotenoids and plasma quercetin increased in the high-vegetable groups in comparison with low-vegetable groups [21]. Furthermore, the high- and low-vegetable groups differed in urinary excretions of several flavonoids [25]. Alpha-tocopherol slightly increased in the groups P1 and P2 $(+0.5 \mu \mathrm{mol} / \mathrm{mmol}$ lipids in both groups) in comparison with groups $\mathrm{M} 1$ and $\mathrm{M} 2(-0.1 \mu \mathrm{mol} / \mathrm{mmol}$ lipids in both groups). Plasma fatty acids reflected diet fatty acid compositions. No differences between the experimental diets in lipoprotein metabolism or markers of lipid peroxidation were seen [21].

\section{Laboratory methods}

Blood samples were taken before and at the end of the dietary period. The samples were taken by trained laboratory nurses from the antecubital vein with minimal stasis after overnight fasting. Vacuum tubes were used (Venoject and Venoject II, Terumo Europe, Leuven, Belgium; Vacuette, Greiner Labortechnic, Kremsmünster, Austria). The laboratory staff were blinded for the treatments and study groups of the subjects.

Blood cells were calculated from EDTA and citrated blood 30 min after sampling with CellDyn 1600 cell counter (Abbott Laboratories, USA) using calibration plasma PAR12 (Streck Laboratories, NB). Citrated blood was used for platelet mean cell volume measurements because platelets may swell in EDTA-blood. For platelet aggregation studies, platelet rich plasma (PRP) was separated from citrated blood by centrifugation $(110 \times \mathrm{g}$ for $10 \mathrm{~min}$ at room temperature) and platelet poor plasma (PPP) by further centrifugation $(2000 \times \mathrm{g}, 10 \mathrm{~min}$, room temperature). Platelet count in PRP was adjusted to $250 \times 10^{9} / \mathrm{L}$ with PPP. Platelet aggregation response to ADP (final concentrations 1 and $2.5 \mu \mathrm{mol} / \mathrm{L}$; Boehringer Mannheim, Germany) and thrombin receptor activating peptide SFLLRN (TRAP) (5 and $10 \mu \mathrm{mol} / \mathrm{L}$; Bachem, Bubendorf, Switzerland) was measured turbidometrically (IIPA-3220-aggregometer, Kyoto Daichi Kagaku Co, Ltd., Japan) within 90 minutes from blood sampling by adding $50 \mu \mathrm{L}$ of aggregating agent in $450 \mu \mathrm{L}$ prewarmed $\left(37^{\circ} \mathrm{C}\right)$ PRP (stirring rate $\left.900 \mathrm{rpm}\right)$. The maximal velocity $(\% / \mathrm{min})$ and maximal aggregation (\%) were recorded.

Protein kinase $\mathrm{C}(\mathrm{PKC})$ is one of the central cell-signalling enzymes in platelets. For PKC activity assays blood was drawn in buffered sodium citrate and samples prepared as described [23]. PKC activity was analysed from the cytosolic and membrane fractions by Biotrak RPN 77 assay (Amersham, Little Chalfont, UK) and standardized by protein concentrations (Bradford reagent, Bio-Rad, CA).

Citrate blood samples from groups P1 $(n=12)$ and 
M2 $(n=13)$ were delivered immediately after sampling to the Platelet Laboratory of the Finnish Red Cross Blood Transfusion Service. Dual-colour staining of blood samples with fluorochrome-labelled monoclonal antibodies [fluorescein isothiosyanate labelled antiCD41 (Biodesign, Kennebunk, ME) and phycoerythrin labelled anti-CD62P (CLB, Netherlands)] was performed for $15 \mathrm{~min}$ at $+37^{\circ} \mathrm{C}$ in the dark. Simultest TM Control g1/g1 (IgG1/IgG1) (Becton Dickinson, San Jose, CA) was employed to detect nonspecific antibody binding. After incubation, $1 \mathrm{~mL}$ of FACSFlow fluid (Becton Dickinson) was added to each tube for flow cytometry (FACScan, Becton Dickinson). 500000 events were acquired and analysed using CellQuest TM software (Becton Dickinson). Analysis was performed on gated platelet populations identified by characteristic forward and $90^{\circ}$ light scatter properties. The percentage of platelets expressing CD62P was defined as the percentage of positive cells compared with the controls.

Plasma soluble P-selectin and intercellular adhesion molecule-1 (ICAM-1) were analysed from lithium heparin plasma with ELISA kits (BBE6 and BBE1B, R\&D Systems, Abingdon, UK). Serum sensitive C-reactive protein (CRP), and antibodies to oxidized LDL, anticardiolipin and prothrombin were analyzed by ELISA assays as described elsewhere [16-18].

All subjects collected three consecutive 24-hour urine samples before and at the end of the experimental period using urine collecting aliquot cups (Daisho co. Ltd, Osaka, Japan) with ascorbic acid as a preservative. Aliquots were stored at $-20^{\circ} \mathrm{C}$. For analysis of the urinary metabolite of thromboxane $\mathrm{A}_{2}, 2,3$-dinor-thromboxane $\mathrm{B}_{2}$ (2,3-dinor-TXB $\left.{ }_{2}\right)$, the three samples were pooled as a 72-hour sample and analyzed enzymoimmunologically as reported [26] using commercial reagents (Cayman Chemicals, Ann Arbor, MI). Urinary creatinine was measured by a colourimetric method (Merckotest \#3384, Merck Diagnostica, Darmstadt, Germany).

\section{Statistics}

All statistical analyses were carried out with the Systat statistical software package (Systat 5.2, SYSTAT Inc, Evanston, IL). Normality of the data was tested by the Lilliefors test and logarithmic transformations were used when necessary. Non-parametric tests were used if logarithmic data were not normally distributed.

Possible differences between the pre-experimental levels in the treatment groups were compared by oneway ANOVA and post hoc test of Tukey or Kruskal-Wallis one way analysis of variance and Mann-Whitney Utest with Bonferroni correction. The treatment effect was calculated as the difference between experimental and pre-experimental values within the groups. The treatment effects of the study groups were compared by one-way ANOVA and post hoc test of Tukey or KruskalWallis one-way analysis of variance and Mann-Whitney U-test with Bonferroni correction. Differences between pre-experimental and experimental values within the treatment groups were tested by paired t-test or Wilcoxon signed ranks test. In all analyses, results with $\mathrm{p}<0.05$ were considered significant.

\section{Results}

The results are shown in Table 3. Platelet count increased in the group P1 but no differences between the treatment groups were seen in platelet count or volume (Table 3). In other blood cell indices no effects between or within groups were seen (data not shown). Because the platelet aggregation results were parallel with ADP 1 and $2.5 \mu \mathrm{mol} / \mathrm{L}$; responses to TRAP $5 \mu \mathrm{mol} / \mathrm{L}$ were weak; and the slope of the aggregation curve and maximal aggregation gave parallel results with both agonists, only maximal aggregation from the higher concentrations of $\operatorname{ADP}(2.5 \mu \mathrm{mol} / \mathrm{L})$ and TRAP $(10 \mu \mathrm{mol} / \mathrm{L})$ are shown in Table 3. Aggregation responses to ADP and TRAP tended to increase in all treatment groups without differences between groups.

Urinary 2,3-dinor- $\mathrm{TXB}_{2}$ tended to decrease in the groups $\mathrm{P} 1$ and $\mathrm{P} 2$ but, possibly due to the large interindividual variation, no significant differences within or between the treatments were seen (Table 3). Mean PKC activities were not differently affected by the diets although PKC activity in the membrane fraction decreased in the group P2. Platelet activation was measured by flow cytometry in subsamples of groups P1 and M2. In the group P1 the proportion of activated cells [mean (SD)] was before the study $2.16 \%(3.78)$ and at the end of the experimental period $3.25 \%$ (6.85). The respective proportions in the group M2 were 2.56 (3.52) and $2.07 \%(2.21)$. Statistical analysis showed no differences between the groups.

Plasma soluble P-selectin was not affected by the treatments (Table 3). Soluble ICAM-1 slightly increased in the group M1 but there were no significant differences between the diets. Serum sensitive CRP decreased in the group P1 without significant differences between groups. The pre-experimental levels of serum anticardiolipid antibodies tended to be low in the groups P1 and P2 and increased during the experimental period but there were no differences between the treatment effects in any of the antiphospholipid antibodies (Table 3). The results of the control group showed no differences between the pre-experimental and experimental values in any variable which indicates absence of period effect in the results (Table 3 ). 
Table 3 Platelet indices, soluble intercellular adhesion molecule-1, C-reactive protein and antiphospholipid antibodies in pre-experimental period and the change during the experimental period. The values are mean (SD)

\begin{tabular}{|c|c|c|c|c|c|c|c|}
\hline \multirow{2}{*}{ Variable } & \multirow{2}{*}{ Perioda } & \multicolumn{4}{|c|}{ Treatment group } & \multirow{2}{*}{$\begin{array}{l}\text { Difference } \\
\text { between groups }\end{array}$} & \multirow[b]{2}{*}{$\begin{array}{l}\text { Control group } \\
n=19\end{array}$} \\
\hline & & $\begin{array}{l}\mathrm{P} 1^{\mathrm{b}} \\
\mathrm{n}=18\end{array}$ & $\begin{array}{l}\mathrm{P} 2 \\
\mathrm{n}=20\end{array}$ & $\begin{array}{l}M 1 \\
n=20\end{array}$ & $\begin{array}{l}M 2 \\
n=19\end{array}$ & & \\
\hline Platelet count $\left(10^{9} / \mathrm{L}\right)$ & $\begin{array}{l}\text { PRE } \\
\text { Change }\end{array}$ & $\begin{array}{l}244(45) \\
12(24)^{d}\end{array}$ & $\begin{array}{l}243(39) \\
-2(28)\end{array}$ & $\begin{array}{l}252(42) \\
-10(30)\end{array}$ & $\begin{array}{l}253(51) \\
-6(40)\end{array}$ & 0.149 & $\begin{array}{l}255(52) \\
-6(29)\end{array}$ \\
\hline Mean platelet volume (fl) & $\begin{array}{l}\text { PRE } \\
\text { Change }\end{array}$ & $\begin{array}{l}7.46(0.89) \\
-0.18(0.51)\end{array}$ & $\begin{array}{l}7.18(0.83) \\
0.04(0.31)\end{array}$ & $\begin{array}{l}7.30(0.98) \\
0.07(0.44)\end{array}$ & $\begin{array}{l}7.39(0.91) \\
0.16(0.44)\end{array}$ & 0.119 & $\begin{array}{l}7.19(1.02) \\
0.22(0.67)\end{array}$ \\
\hline $\begin{array}{l}\text { Aggregation to ADP } \\
2.5 \mu \mathrm{mol} / \mathrm{L}(\%)\end{array}$ & $\begin{array}{l}\text { PRE } \\
\text { Change }\end{array}$ & $\begin{array}{l}55.8(21.5) \\
9.6(13.6)^{d}\end{array}$ & $\begin{array}{l}43.6(22.5) \\
13.3(24.0)^{d}\end{array}$ & $\begin{array}{l}42.8(24.1) \\
20.9(22.2)^{d}\end{array}$ & $\begin{array}{l}48.2(22.7) \\
9.6(14.8)^{d}\end{array}$ & 0.244 & $\begin{array}{l}44.6(27.2) \\
9.0(21.1)\end{array}$ \\
\hline $\begin{array}{l}\text { Aggregation to TRAP } \\
10 \mu \mathrm{mol} / \mathrm{L}(\%)\end{array}$ & $\begin{array}{l}\text { PRE } \\
\text { Change }\end{array}$ & $\begin{array}{l}43.1(28.3) \\
7.2(17.3)^{d}\end{array}$ & $\begin{array}{l}31.7(24.4) \\
14.7(27.6)^{d}\end{array}$ & $\begin{array}{l}25.2(22.9) \\
27.9(31.4)^{d}\end{array}$ & $\begin{array}{l}41.9(30.4) \\
2.0(27.5)\end{array}$ & 0.126 & $\begin{array}{l}30.5(31.3) \\
4.2(25.2)\end{array}$ \\
\hline \multirow[t]{2}{*}{$\begin{array}{l}\text { Urinary 2,3-dinor-TXB }{ }_{2} \\
\text { (pg/mg crea) }\end{array}$} & $\begin{array}{l}\text { PRE } \\
\text { Change }\end{array}$ & $\begin{array}{l}995(547) \\
-206(550)\end{array}$ & $\begin{array}{l}896(815) \\
-170(773)\end{array}$ & $\begin{array}{l}871(648) \\
-72(575)\end{array}$ & $\begin{array}{l}847(345) \\
-59(401)\end{array}$ & 0.849 & $\begin{array}{l}622(265) \\
11(209)\end{array}$ \\
\hline & & $\mathrm{n}=12$ & $\mathrm{n}=15$ & $\mathrm{n}=17$ & $n=13$ & & $\mathrm{n}=15$ \\
\hline $\begin{array}{l}\text { Cytosolic PKC activity } \\
\text { (pmol/min/mg prot) }\end{array}$ & $\begin{array}{l}\text { PRE } \\
\text { Change }\end{array}$ & $\begin{array}{l}1785(570) \\
170(643)\end{array}$ & $\begin{array}{l}1755(491) \\
161(752)\end{array}$ & $\begin{array}{l}1634(609) \\
173(905)\end{array}$ & $\begin{array}{l}1724(432) \\
96(376)\end{array}$ & 0.991 & $\begin{array}{l}1931(400) \\
415(894)\end{array}$ \\
\hline \multirow[t]{2}{*}{$\begin{array}{l}\text { Membrane PKC activity } \\
\text { (pmol/min/mg prot) }\end{array}$} & $\begin{array}{l}\text { PRE } \\
\text { Change }\end{array}$ & $\begin{array}{l}1485(1045) \\
-74(500)\end{array}$ & $\begin{array}{l}1628(841) \\
-238(496)^{d}\end{array}$ & $\begin{array}{l}1489(902) \\
-229(743)\end{array}$ & $\begin{array}{l}1476(705) \\
4(597)\end{array}$ & 0.651 & $\begin{array}{l}1259(553) \\
38(636)\end{array}$ \\
\hline & & $\mathrm{n}=18$ & $\mathrm{n}=20$ & $\mathrm{n}=20$ & $\mathrm{n}=19$ & & $\mathrm{n}=19$ \\
\hline Plasma P-selectin (ng/mL) & $\begin{array}{l}\text { PRE } \\
\text { Change }\end{array}$ & $\begin{array}{l}50.6(17.7) \\
0.2(6.2)\end{array}$ & $\begin{array}{l}48.1(13.8) \\
-0.8(6.0)\end{array}$ & $\begin{array}{l}52.6(16.2) \\
0.8(4.3)\end{array}$ & $\begin{array}{l}48.3(15.6) \\
-0.2(5.0)\end{array}$ & 0.819 & $\begin{array}{l}71.7(50.4) \\
-16.8(47.9)\end{array}$ \\
\hline Plasma ICAM-1 (ng/mL) & $\begin{array}{l}\text { PRE } \\
\text { Change }\end{array}$ & $\begin{array}{l}203.3(55.9) \\
-2.2(26.7)\end{array}$ & $\begin{array}{l}212.7(83.4) \\
-1.0(38.9)\end{array}$ & $\begin{array}{l}223.5(59.0) \\
15.0(27.2)^{d}\end{array}$ & $\begin{array}{l}215.3(69.4) \\
1.6(31.2)\end{array}$ & 0.318 & $\begin{array}{l}211.4(33.1) \\
-3.8(25.1)\end{array}$ \\
\hline Serum CRP $(\mu \mathrm{g} / \mathrm{mL})$ & $\begin{array}{l}\text { PRE } \\
\text { Change }\end{array}$ & $\begin{array}{l}3.11(4.79) \\
-2.00(4.74)^{d}\end{array}$ & $\begin{array}{l}2.61(4.07) \\
1.27(7.21)\end{array}$ & $\begin{array}{l}6.41(13.88) \\
-4.18(12.98)\end{array}$ & $\begin{array}{l}3.61(5.03) \\
-1.92(5.04)\end{array}$ & 0.264 & $\begin{array}{l}3.11(8.34) \\
-1.80(8.14)\end{array}$ \\
\hline $0 x-L D L A b(0 D)$ & $\begin{array}{l}\text { PRE } \\
\text { Change }\end{array}$ & $\begin{array}{l}0.112(0.052) \\
0.004(0.041)\end{array}$ & $\begin{array}{l}0.142(0.080) \\
0.006(0.034)\end{array}$ & $\begin{array}{l}0.112(0.051) \\
0.001(0.031)\end{array}$ & $\begin{array}{l}0.140(0.060) \\
-0.003(0.027)\end{array}$ & 0.668 & $\begin{array}{l}0.083(0.053) \\
-0.001(0.023)\end{array}$ \\
\hline Anticardiolipin Ab (OD) & $\begin{array}{l}\text { PRE } \\
\text { Change }\end{array}$ & $\begin{array}{l}0.045(0.017) \\
0.006(0.010)^{d}\end{array}$ & $\begin{array}{l}0.043(0.015) \\
0.009(0.013)^{d}\end{array}$ & $\begin{array}{l}0.070(0.045) \\
0.005(0.024)\end{array}$ & $\begin{array}{l}0.086(0.065) \\
0.019(0.065)\end{array}$ & 0.415 & $\begin{array}{l}0.033(0.016) \\
0.006(0.014)\end{array}$ \\
\hline Prothrombin Ab (OD) & $\begin{array}{l}\text { PRE } \\
\text { Change }\end{array}$ & $\begin{array}{l}0.144(0.048) \\
0.009(0.051)\end{array}$ & $\begin{array}{l}0.148(0.042) \\
0.006(0.037)\end{array}$ & $\begin{array}{l}0.142(0.053) \\
0.005(0.038)\end{array}$ & $\begin{array}{l}0.181(0.155) \\
0.008(0.043)\end{array}$ & 0.962 & $\begin{array}{l}0.125(0.120) \\
0.045(0.125)\end{array}$ \\
\hline
\end{tabular}

a PRE pre-experimental period; Change EXP-PRE (EXP = experimental period)

b The treatment groups are named according to the experimental diets: $P 1$ rich in linoleic acid and low in vegetables; $P 2$ rich in linoleic acid and high in vegetables, berries and apple; $M 1$ rich in oleic acid and low in vegetables; and $M 2$ rich in oleic acid and high in vegetables, berries and apple

c $p$-value of difference between the treatment effects in the dietary groups. The data was tested by comparing the changes by one-way analysis of variance or by KruskallWallis one-way analysis of variance

d Significant difference between PRE and EXP values within the treatment group $(p<0.05$, paired t-test or Wilcoxon signed ranks test)

\section{Discussion}

Our aim was to find out whether isocaloric diets with large or small amounts of vegetables, berries and apple affect various markers associated with the risk of coronary heart disease differently. Compliance with the experimental diets was verified by biomarkers [21,25]. The present results show that none of the experimental diets could markedly modify the markers of platelet activation or inflammation in our healthy volunteers.

Vegetables, berries and apple are rich sources of flavonoids. There is much data indicating that flavonoids could modulate platelet activation and function by several mechanisms at least in vitro. Usually in concentrations higher than nutritionally achievable, flavonoids have been shown e.g. to inhibit platelet aggregation [7,9, 27] and alter pathways involved in platelet activation such as cyclic AMP levels, arachidonic acid metabolism, phospholipase $C$ pathway and nitric oxide production $[8$, 9, 28-30]. Enzyme inhibiting effects presumably require intracellular presence but flavonoids can also affect platelet function without entering the platelet e.g. via thromboxane receptor antagonism [8]. 
Despite several possible mechanisms, platelet effects have rarely been shown in controlled human interventions with foods or beverages rich in flavonoids. Platelet aggregation has not been modified by onion and parsley supplementation [7], black tea [31,32] or sea buckthorn juice ingestion [33]. Furthermore, the diminuation in platelet aggregation after red wine exposure seems to be due to ethanol rather than red wine phenolics $[34,35]$. Green tea extract supplementation has also been shown ineffective with respect to urinary 2,3-dinor- $\mathrm{TXB}_{2}$ [36]. In the present study, the calculated flavonoid intakes in the high-vegetable diets compared with the lowvegetable diets were as high as 10 -fold. However, no differences in platelet indices were seen. Quercetin concentrations in fasting plasma significantly increased in the high-vegetable groups during the experimental period but the average levels did not exceed $140 \mathrm{nmol} / \mathrm{L}$ [21]. It seems plausible that the bioavailability of most dietary flavonoids is too low to result in platelet effects in vivo at least in fasting conditions. The acute effects of flavonoids have been less studied. There are, however, studies which show decreased platelet aggregation after ingestion of red grape juice [37] and decreased flow-cytometrically measured platelet activation after cocoa ingestion [38]. In both studies, platelet aggregability did not decrease after other flavonoid-rich beverages. The fact that we did not detect any platelet effects by highvegetable diets does not exclude the possibility that concentrated sources of specific flavonoids can have postprandial platelet effects. The biological significance of such short-term effects in the prevention of CHD remains, however, to be proven.

In the present setting, we also modified the volunteers' intakes of carotenoids as well as vitamin $\mathrm{C}$ and vitamin $\mathrm{E}$. Sea buckthorn juice which is rich not only in flavonoids but also in vitamin $\mathrm{C}$ and carotenoids, did not affect platelet ex vivo aggregability when drunk for 8 weeks [33]. However, supplementation studies have shown that pharmacological doses of a mixture of vitamin $C$, vitamin $E$ and $\beta$-carotene or vitamin $E$ alone decrease platelet aggregation to ADP especially if the baseline vitamin status is poor $[4,5]$. Vitamin $C$ or $\beta$-carotene supplementation alone have shown no effects [5]. In addition to $\alpha$-tocopherol, other tocopherols also seem to have anti-platelet effects [39]. Tocopherols decrease platelet activation via PKC inhibition $[6,39]$ but also nitric oxide release and superoxide dismutase amount have been reported to be modulated by tocopherol supplementation [39]. In the present study, the amount of $\alpha$ tocopherol was higher in the high-linoleic acid diets than in the high-oleic acid diets which was also reflected in plasma $\alpha$-tocopherol concentrations [21]. The differences in $\alpha$-tocopherol concentrations were probably far too modest to affect platelet function.

$\mathrm{P}$-selectin is an adhesion molecule which mediates leucocyte rolling on endothelium. It is expressed by ac- tivated endothelial cells and platelets, and its plasma concentrations can be used as an in vivo marker of the activation of these cells $[40,41]$. Soluble P-selectin has been shown to be associated with the risk of future cardiovascular events in women [42]. Our results indicate that soluble P-selectin is not easily affected by dietary means. However, Hodgson et al. [32] reported a decrease in plasma P-selectin concentration by black tea ingestion.

In the present study, P-selectin positive platelets were also measured as a marker of platelet activation status in vivo. The subgroup of volunteers for these flow-cytometrical analyses was picked up from the low-vegetable high-linoleic acid group P1 and the high-vegetable higholeic acid group M2. The average activation levels were low in our healthy subjects and, although there was a tendency towards enhanced activity in the group P1 and decreased activity in the group M2, no differences between the diets could be statistically detected. Cocoa ingestion has been reported to decrease the numbers of $\mathrm{P}$ selectin positive platelets in a postprandial study [38].

ICAM-1 is an another endothelial adhesion molecule which mediates the adhesion of leucocytes on the endothelial surface. Soluble ICAM-1 has been strongly associated with the risk of ischemic heart disease [10]. Antioxidants could affect ICAM- 1 because its expression is mediated via the transcription factor nuclear factor $-\kappa B$ which is stimulated by cellular oxidative stress [43]. We saw no differences in ICAM-1 between the high vs. low vegetable groups. Neither black tea nor sea buckthorn juice have affected soluble ICAM-1 in earlier studies [32, 33].

The acute phase protein CRP has been recognised as a powerful predictor of cardiovascular risk [10]. In the present study, the dietary factors did not cause changes in the concentration of CRP. Earlier data on dietary effects on CRP is scarce but in one study it was not affected by black or green tea consumption [44]. We measured also serum antiphospholipid antibodies which have been shown to be associated with increased risk of coronary events in case-control studies [16-18]. There is indirect evidence that diet could modify antiphospholipid antibody formation in oxidative stress. In male cigarette smokers plasma vitamin $\mathrm{C}$, but not vitamin $\mathrm{E}$ or $\beta$ carotene, was inversely associated with antibodies to cardiolipin and oxidized LDL [45]. Furthermore, in diabetic patients high levels of antibodies to oxidized LDL were associated with high proportion of polyunsaturated fatty acids in LDL [46]. The antibody levels were low in our healthy volunteers and no differences between the groups were seen. Our finding is in concordance with that of O'Reilly et al. [47] who found no changes in antibodies to oxidized LDL in healthy volunteers consuming large amounts of tea and onions. It is possible that the effect of dietary factors on the production of antiphospholipid antibodies could be detectable 
only in subjects with increased antibody levels due to an underlying pro-oxidative stimulus, such as smoking and stress.

\section{Conclusions}

In this highly controlled human intervention study diets rich or poor in vegetables, berries and apple did not differ in their effects on the wide range of markers related to platelet and endothelial function and inflammation. The overall conclusion of the present study is that in healthy volunteers with adequate habitual diet, only marginal effects on markers associated with platelets or inflammation can be achieved by modulating the intakes of vegetables and fruit or unsaturated fatty acids.
The present results do not indicate that platelet function or inflammation are the processes in the pathophysiology of CHD favourably affected by diets high in vegetables and fruits. However, our results do not exclude the possibility that in different populations e.g. among heavy smokers or subjects with marginal antioxidant intake, diets comparable to ours could have different effects.

Acknowledgments The study has been financially supported by the Ministry of Agriculture and Forestry, the University of Helsinki, the Academy of Finland (project 10141399), the Juho Vainio Foundation and the Finnish Horticultural Products Society. Raisio Margarine donated the study fats. All are gratefully acknowledged. The thanks are extended to MSc Kaija Javela from the Finnish Red Cross Blood Transfusion Service for the platelet activation analyses and MD Timo Palosuo from the National Public Health Institute for CRP analyses.

\section{References}

1. Hu FB, Willett WC (2002) Optimal diets for prevention of coronary heart disease. JAMA 288:2569-2578

2. Hornstra G (2001) Influence of dietary fat type on arterial thrombosis tendency. J Nutr Health Aging 5:160-166

3. Iuliano L, Colavita AR, Leo R, Pratico D, Violi F (1997) Oxygen free radicals and platelet activation. Free Radical Biol Med 22:999-1006

4. Salonen JT, Salonen R, Seppänen K, Rinta-Kiikka S, Kuukka M, Korpela H, Alfthan G, Kantola M, Schalch W (1991) Effects of antioxidant supplementation on platelet function: a randomized pairmatched, placebo-controlled, doubleblind trial in men with low antioxidant status. Am J Clin Nutr 53:1222-1229

5. Calzada C, Bruckdorfer K, Rice-Evans C (1997) The influence of antioxidant nutrients on platelet function in healthy volunteers. Atherosclerosis 128:97-105

6. Steiner M (1999) Vitamin E, a modifier of platelet function: rationale and use in cardiovascular and cerebrovascular disease. Nutr Rev 57:306-309

7. Janssen PK, Mensink RP, Cox FJ, Harryvan JL, Hovenier R, Hollman PCH, Katan MB (1998) Effects of the flavonoids quercetin and apigenin on hemostasis in healthy volunteers: results from an in vitro and a dietary supplement study. Am J Clin Nutr 67: 255-262

8. Middleton E, Kandaswami C, Theoharides TC (2000) The effects of plant flavonoids on mammalian cells: implications for inflammation, heart disease, and cancer. Pharmacol Rew 52:673-751

9. Freedman JE, Parker G, Li L, Perlman JA, Frei B, Ivanov V, Deak LR, Iafrati MD, Folts JD (2001) Select flavonoids and whole juice from purple grapes inhibit platelet function and enhance nitric oxide release. Circulation 103:2792-2798
10. Blake GJ, Ridker PM (2001) Novel clinical markers of vascular wall inflammation. Circ Res 89:763-771

11. Libby P (2002) Inflammation in atherosclerosis. Nature 420:868-874

12. Vita JA, Keaney JF (2002) Endothelial function: a barometer for cardiovascular risk? Circulation 106:640-642

13. Brown AA, Hu FB (2001) Dietary modulation of endothelial function: implications for cardiovascular disease. Am J Clin Nutr 73:673-686

14. Calder PC (2002) Dietary modification of inflammation with lipids. Proc Nutr Soc 61:345-358

15. Field CJ, Johnson IR, Schley D (2002) Nutrients and their role in host resistance to infection. J Leukoc Biol 71: $16-32$

16. Puurunen $M$, Mänttäri $M$, Manninen $V$, Tenkanen L, Alfthan G, Enholm C, Vaarala O, Aho K, Palosuo T (1994) Antibody against oxidized low-density lipoprotein predicting myocardial infarction. Arch Intern Med 154: 2605-2609

17. Vaarala $O$, Mänttäri $M$, Manninen V, Tenkanen L, Puurunen M, Aho K, Palosuo T (1995) Anti-cardiolipin antibodies and risk of myocardial infarction in a prospective cohort of middle-aged men. Circulation 91:23-27

18. Vaarala $O$, Puurunen $M$, Mänttäri $M$, Manninen V, Aho K, Palosuo T (1996) Antibodies to prothrombin imply a risk of myocardial infarction in middle-aged men. Thromb Haemostas 75:456-459

19. Martinuzzo ME, Forastiero RR, Kordich L, Carreras LO (2001) Increased lipid peroxidation correlates with platelet activation but not with markers of endothelial cell and blood coagulation activation in patients with antiphospholipid antibodies. Br J Haematol 114: 845-851
20. Nestle M (1996) Fruits and vegetables: protective or just fellow travelers? Nutr Rev 54:255-257

21. Freese R, Alfthan G, Jauhiainen M, Basu S, Erlund I, Salminen I, Aro A, Mutanen M (2002) High intakes of vegetables, berries and apple combined with high intake of linoleic or oleic acid only slightly affects markers of lipid peroxidation and lipoprotein metabolism in healthy subjects. Am J Clin Nutr 76: 950-960

22. Mutanen M, Freese R, Valsta LM, Ahola I, Ahlström A (1992) Rapeseed oil and sunflower oil diets enhance platelet in vitro aggregation and thromboxane production in healthy men when compared with milk fat or habitual diets. Thromb Haemostas 67:352-356

23. Turpeinen AM, Pajari A-M, Freese R, Sauer R, Mutanen M (1998) Replacement of dietary saturated by unsaturated fatty acids: effects on platelet protein kinase $\mathrm{C}$ activity, urinary content of 2,3-dinor- $\mathrm{TXB}_{2}$ and in vitro platelet aggregation in healthy men. Thromb Haemost 80:649-655

24. Hunter KA, Crosbie LC, Weir A, Miller GJ, Dutta-Roy AK (2000) A residential study comparing the effects of diets rich in stearic acid, oleic acid, and linoleic acid on fasting blood lipids, hemostatic variables and platelets in young healthy men. J Nutr Biochem 11: 408-416

25. Nielsen SE, Freese R, Kleemola P, Mutanen M (2002) Flavonoids in human urine as biomarkers for intake of fruits and vegetables. Cancer Epidemiol Biomarkers Prev 11:459-466

26. Freese R, Mutanen M (1997) Alphalinolenic acid and marine long-chain n3 fatty acids only slightly differ in their effects on hemostatic factors in healthy subjects. Am J Clin Nutr 66:591-598 
27. Pace-Asciak CR, Hahn S, Diamandi EP Soleas G, Goldberg DM (1995) The red wine phenolics trans-resveratrol and quercetin block human platelet aggregation and eicosanoid synthesis: implications for protection against coronary heart disease. Clin Chem Acta 235: 207-219

28. Landolfi R, Mower RL, Steiner M (1984) Modification of platelet function and arachidonic acid metabolism by bioflavonoids. Structure-activity relations. Biochem Pharmacol 33:1525-1530

29. Corvazier E, Maclouf J (1985) Interference of some flavonoids and nonsteroidal anti-inflammatory drugs with oxidative metabolism of arachidonic acid by human platelets and neutrophils. Biochim Biophys Acta 835: 315-321

30. Pignatelli P, Pulcinelli FM, Celestini A, Lenti L, Ghiselli A, Gazzaniga PP, Violi F (2000) The flavonoids quercetin and catechin synergistically inhibit platelet function by antagonizing the intracellular production of hydrogen peroxide. Am J Clin Nutr 72:1150-1155

31. Duffy SJ, Vita JA, Holbrook M, Swerdloff PL, Keaney JF (2001) Effect of acute and chronic tea consumption on platelet aggregation in patients with coronary artery disease. Arterioscler Thromb Vasc Biol 21:1084-1089

32. Hodgson JM, Puddey IB, Mori TA, Burke V, Baker RI, Beilin LJ (2001) Effects of regular ingestion of black tea on haemostasis and cell adhesion molecules in humans. Eur J Clin Nutr 55: 881-886

33. Eccleston C, Baoru Y, Tahvonen R, Kallio H, Rimbach GH, Minihane AM (2002) Effects of an antioxidant-rich juice (sea buckthorn) on risk factors for coronary heart disease in humans. J Nutr Biochem 13:346-354
34. Pace-Asciac CR, Rounova O, Hahn SE, Diamandis EP, Goldberg DM (1996) Wines and grape juices as modulators of platelet aggregation in healthy human subjects. Clin Chem Acta 246: 163-182

35. Pellegrini N, Pareti FI, Stabile F, Brusamolino A, Simonetti P (1996) Effects of moderate consumption of red wine on platelet aggregation and haemostatic variables in healthy volunteers. Eur J Clin Nutr 50:209-213

36. Freese R, Basu S, Hietanen E, Nair J, Nakachi K, Bartsch $H$, Mutanen M (1999) Green tea extract decreases plasma malondialdehyde concentration but does not affect other indicators of oxidative stress, nitric oxide production, or hemostatic factors during a high-linoleic acid diet in healthy females. Eur J Nutr 38:149-157

37. Keevil JG, Osman HE, Reed JD, Folts JD (2000) Grape juice, but not orange juice or grapefruit juice, inhibits human platelet aggregation. J Nutr 130:53-56

38. Rein D, Paglieroni TG, Pearson DA, Wun D, Schmitz HH, Gosselin R, Keen CL (2000) Cocoa and wine polyphenols modulate platelet activation and function. J Nutr 130:2120S-2126S

39. Liu M, Wallmon A, Olsson-Mortlock C, Wallin R, Saldeen T (2003) Mixed tocopherols inhibit platelet aggregation in humans: potential mechanisms. Am J Clin Nutr 77:700-706

40. Blann AD, Lip GYH (1997) Hypothesis: is soluble P-selectin a new marker of platelet activation? Atherosclerosis 128: 135-138
41. Davi G, Romano M, Mezzetti A, Procopio A, Iacobelli S, Antidormi T, Bucciarelli T, Alessandrini P, Cuccurullo F, Bon GB (1998) Increased levels of soluble Pselectin in hypercholesterolemic patients. Circulation 97:953-957

42. Ridker PM, Buring JE, Rifai N (2001) Soluble P-selectin and the risk of future cardiovascular events. Circulation 103: 491-495

43. Collins T, Cybulsky MI (2001) NF-кB: pivotal mediator or innocent bystander in atherogenesis? J Clin Invest 107: 255-264

44. de Maat MPM, Pijl H, Kluft C, Princen HMG (2000) Consumption of black and green tea has no effect on inflammation, haemostasis and endothelial markers in smoking healthy individuals. Eur J Clin Nutr 54:757-763

45. Fickl H, Van Antwerpen VL, Richards GA, van der Westhuyzen DR, Davies N, van der Walt R, van der Merwe CA, Anderson R (1996) Increased levels of autoantibodies to cardiolipin and oxidised low-density lipoprotein are inversely associated with plasma vitamin C status in cigarette smokers. Atherosclerosis 124:75-81

46. Griffin ME, McInerney D, Fraser A, Johnson AH, Collins PB, Owens D, Tomkin GH (1997) Autoantibodies to oxidized low density lipoprotein: the relationship to low density lipoprotein fatty acid composition in diabetes. Diabet Med 14:741-747

47. O’Reilly JD, Mallet AI, McAnlis GT, Young IS, Halliwell B, Sanders TAB, Wiseman H (2001) Consumption of flavonoids in onions and black tea: lack of effect on F2-isoprostanes and autoantibodies to oxidized LDL in healthy humans. Am J Clin Nutr 73:1040-1044 